\title{
WORKSHOP PHOTO EDITING SEBAGAI BEKAL WIRAUSAHA BAGI KARANG TARUNA KECAMATAN GONDANG MOJOKERTO
}

\author{
Liknin Nugraheni $^{1)}$, Sri Rahayu ${ }^{2}$, Sunyoto Hadi Prayitno ${ }^{3)}$, Erlin Ladyawati ${ }^{4}$, Moh. Syukron \\ Maftuh $^{5)}$, Nur Fathonah ${ }^{\text {() }}$ \\ 1, 2, 3, 4, 5, 6 FKIP, Universitas PGRI Adi Buana Surabaya
}

Email: liknin@unipasby.ac.id; yayukunipa@gmail.com; nyoto hp@unipasby.ac.id; erlin@unipasby.ac.id; syukron@unipasby.ac.id; nurfathonah@unipasby.ac.id

\begin{abstract}
Abstrak
Berdasarkan hasil survey dan observasi pada pemuda dan pemudi karang taruna yang ada di Kecamatan Gondang Kabupaten Mojokerto ini, menunjukkan bahwa masih banyak dari mereka yang masih belum memiliki pekerjaan atau bisa dikatakan bahwa mereka belum belum bisa mendapatkan penghasilan. Salah satu factor yang berhasil kami himpun adalah dikarenakan masih kurangnya keterampilan yang mereka miliki. Hal tersebut disebabkan oleh para pemuda dan pemudi karang taruna tidak pernah memperoleh bimbingan baik dari pendidikan formal ataupun dengan cara mengikuti pelatihan-pelatihan yang dapat mengarahkan para pemuda pemudi karang taruna pada pengetahuan luas, khususnya yang berkenaan dengan photo editing. Berdasarkan masalah tersebut, maka tim pelaksana PPM prodi pendidikan matematika FKIP Unipa Surabaya, akan melaksanakan Workshop photo editing dengan memanfaatkan aplikasi adobe photoshop. Kegiatan tersebut, mampu menambah referensi dan pengetahuan bagi pemuda karang taruna yang ada di Kecamatan Gondang terutama di bidang desain grafis khususnya photo editing. Setelah mengikuti workshop, para karang taruna yang dapat mengedit foto secara sederhana dan mengaplikasikannya dalam berbagai macam bentuk publikasi cetak seperti logo, pamflet, brosur, ekartu nama, eposter, buku, tata letak/layout majalah, desain iklan, undangan, cover majalah, dan lain sebagainya akan mampu mengembangkan jiwa entrepreneur dibidang photo editing, sehingga dapat dijadikan lapangan pekerjaan.
\end{abstract}

Kata kunci: Photo editing, wirausaha, karang taruna, kecamatan gondang.

\begin{abstract}
The results of surveys and observations of karang taruna (youth organization) in the Gondang subdistrict, the district of Mojokerto shows that there are still many of unemployed youths and not able to make an income. One of the factors is that they were unskilled because of never having formal education or training programs. The training program which potentially helped them was photo editing. Based on these problems, the research and community services team of Mathematics Education Study Program, faculty of teacher and Education, UNIPA Surabaya held a photo editing workshop by using Adobe Photoshop application. The activity was able to increase references and knowledge for Karang Taruna in graphic design, especially photo editing. After attending the workshop, they could edit photos simply and apply them in various forms of printed publications such as logos, pamphlets, brochures, business cards, posters, books, magazine layouts, advertisement designs, invitations, magazine covers and others. Thus, it can be concluded that this skill could develop entrepreneurial spirit of Karang taruna in photo editing and provide vocation opportunity.
\end{abstract}

Keywords: Photo Editing, entrepreneurship, youth organization, gondang sub-district. 


\section{PENDAHULUAN}

Karang taruna adalah suatu organisasi sosial kemasyarakatan di tingkat Desa/Kelurahan yang digunakan sebagai tempat dan sarana tumbuh dan berkembang bagi pemuda dan pemudi demi kesejahteraan sosial. Salah satu karang taruna yang menjadi sasaran dalam kegiatan PPM ini adalah karang taruna yang ada di Kecamatan Gondang Kabupaten Mojokerto yang meliputi 18 Kelurahan yaitu: (1) Kelurahan Bakalan, (2) Kelurahan Begaganlimo, (3) Kelurahan Bening, (4) Kelurahan Centong, (5) Kelurahan Dilem, (6) Kelurahan Gondang, (7) Kelurahan Gumeng, (8) Kelurahan Jatidukuh, (9) Kelurahan Kalikatir, (10) Kelurahan Karangkuten, (11) Kelurahan Kebontunggal, (12) Kelurahan Kemasantani, (13) Kelurahan Ngembat, (14) Kelurahan Padi, (15) Kelurahan Pohjejer, (16) Kelurahan Pugeran, (17) Kelurahan Tawar, (18) Kelurahan Wonoploso. Berdasarkan hasil observasi dan survey yang telah dilakukan oleh tim PPM Prodi, hasilnya bahwa masih banyak dari para karang taruna yang ada di Kecamatan Gondang Mojokerto yang memiliki ketrampilan minim sehingga minim pula dalam mengembangkan diri demi tercapainya kesejahteraan sosial atau biasa dikatakan masih banyak yang menganggur.

Tidak hanya di kota-kota besar masalah rendahnya tingkat keterampilan dan pemahaman pada karang taruna terhadap pentingnya penggunaan photo editing untuk bekal kewirausahaan terutama di pinggiran kota/desa, seperti yang dialami oleh karang tarunasyangsada di Kecamatan Gondang, Kabupaten Mojokerto. Berdasarkan hasil wawancara langsung dengan beberapa ketua pengurus pemuda pemudi karang taruna yang terdapat di Kecamatan Gondang Kabupaten Mojokerto dan didukung oleh hasil survei lapangan yang dilakukan oleh tim prodi, menunjukkan bahwa masih banyak para pemuda pemudi karang taruna yang ada di wilayah Kecamatan Gondang Kabupaten Mojokerto yang masih sangat kurang dalam memahami pentingnya penggunaan photo editing. \begin{tabular}{lrrr}
\multicolumn{3}{c}{ Berdasarkan masalah di atas, tim } \\
pelaksana PPM akan melaksanakan \\
Workshop photo editing dengan
\end{tabular} memanfaatkan Aplikasi Adobe Photoshop. Dengan menguasai program-program aplikasi desain grafis khususnya photo editing maka para peserta kegiatan PPM ini diharapkan akan dapat mengedit foto secara sederhana dan mengaplikasikannya dalam berbagai macam bentuk publikasi cetak seperti logo, pamflet, brosur, kartu nama, poster, ebuku, tata letak/layout dll. Target akhir dari pelatihan desain grafis ini adalah peserta kegiatan dapat menguasai dengan baik pengolahan gambar untuk berbagai keperluan. Tidak hanya untuk kepentingan organisasi saja, tetapi juga bias untuk diri sendiri.

\section{KAJIAN LITERATUR}

\subsection{KARANG TARUNA}

Berdasarkan beberapa pendapat ahli mengatakan bahwa: "Karang Taruna adalah organisasi kepemudaan di Indonesia. Karang Taruna merupakan wadah pengembangan generasi muda nonpartisan, yang tumbuh atas dasar kesadaran dan rasa tanggung jawab sosial dari, soleh dan untuk masyarakat khususnya generasi muda di wilayah Desa/Kelurahan atau komunitas social sederajat, yang terutama bergerak dibidang kesejahteraan sosial. Sebagai organisasi sosial kepemudaan Karang Taruna merupakan wadah pembinaan dan pengembangan serta pemberdayaan dalam upaya mengembangkan kegiatan ekonomis produktif dengan pendayagunaan semua potensi yang tersedia dilingkungan baik sumber daya manusia maupun sumbersdaya alam yang telah ada. Sebagai organisasi kepemudaan, Karang Taruna berpedoman pada Pedoman Dasar dan Pedoman Rumah Tangga di mana telah pula diatur tentang struktur penggurus dan masa jabatan dimasing-masing wilayah mulai dari Desa/Kelurahan sampai pada tingkat Nasional. Semua ini wujud dari pada regeneras sorganisasi demi kelanjutan organisasi serta pembinaan anggota karang taruna baik dimasa sekarang maupun masa 
yang akan datang. Karang taruna beranggotakan pemuda dan pemudi (dalam AD/ART nya diatur keanggotaannyasmulai dari pemuda/i berusia mulai daris11 - 45 tahun) dan batasan sebagai Pengurus adalah berusia mulais 17 - 35 tahun. Karang Taruna didirikan dengan tujuan memberikan pembinaan dan pemberdayaan kepada para remaja, misalnya dalam bidang keorganisasian, ekonomi, olahraga, ketrampilan, advokasi, keagamaansdan kesenian".

\subsection{DESAIN GRAFIS}

Terdapat banyak sekali aplikasi desain grafis yang biasa digunakan untuk belajar desain. Yang paling popular di kalangan umum dan bahkan menjadi standar industry adalah didominasi oleh produk-produk yang dikelarkan oleh adobe. Yang kehebatannya tidak perlu diragukan lagi. Selain Photoshop yang biasa digunakan untuk editing photo, masih ada lagi aplikasi desain grafis untuk urusan membuat desain vektor. Contoh aplikasi desaineyang biasa digunakan dalam kategori ini adalah AdobeeIlustrator dan Corel DRAW. Dengan menggunakan aplikasi-aplikasi tersebut, banyakorang dapat membuat logo, karakter animasi, desain brosur, kalender, poster, danemasih banyak lagi.

Desain grafis saat ini begitu banyak diminati dalam berbagai perusahaan. Dengan menggunakan desain yang terencana dan tepat sasaran kepada target marketnya akan mampu meningkatkan penjualan.

Dalam kehidupan berogranisasi sekelas Karang Taruna sendiri, keterampilan menggunakan aplikasi desain grafis tentunya sangat berguna. Selain untuk kepentingan publikasi seperti pembuatan banner $-\mathrm{X}$ banner, brosur, pamflet dan undangan-saat ingin melangsung sebuah perhelatan, juga pembuatan kartu nama, desain grafis juga dapat berguna untuk meningkatkan skill para anggota untuk selanjutnya dapat dikembangkan dalam dunia berwirausaha.

\subsection{ADOBE PHOTOSHOP}

2.3.1 Fitur-Fitur dalam Adobe Photoshop Adobe photoshop merupakan suatu software editing yang popular atau biasa dikatakan biasa dipakai di kalangan fotografer profesional. Untuk menghasilkan gambar yang berkualitas tinggi, Photoshop menyediakan banyak alat baru dan fitur-fitur yang cerdas serta beragam guna mempermudah pekerjaan para penggunanya. Berikut beberapa fitur keren untuk edit foto dengan photoshop: (1) Gunakan Color Effect dengan sekalieklik, (2) Menambah Glyphs yangetersembunyi, (3) Unduhefree efekefoto higheend di PhotoshopePlugin, (4) Menulis teks dengan Variable Fonts, (5) Curvature PeneTool untuk menggambar, (6) Memperindah ilustrasi dengan goresan kuas Brush Smoothing.

\subsubsection{Mengenal Area Kerja (Work place) Adobe Photoshop}

Adobe Photoshop inieadalah suatu produk dari ADOBE yang diluncurkan untuk mengolah/mengedit photo. Berikut ini adalah contoh area Kerja Adobe Photoshop yang dapat diperhatikan dalam Gambar 1 . 


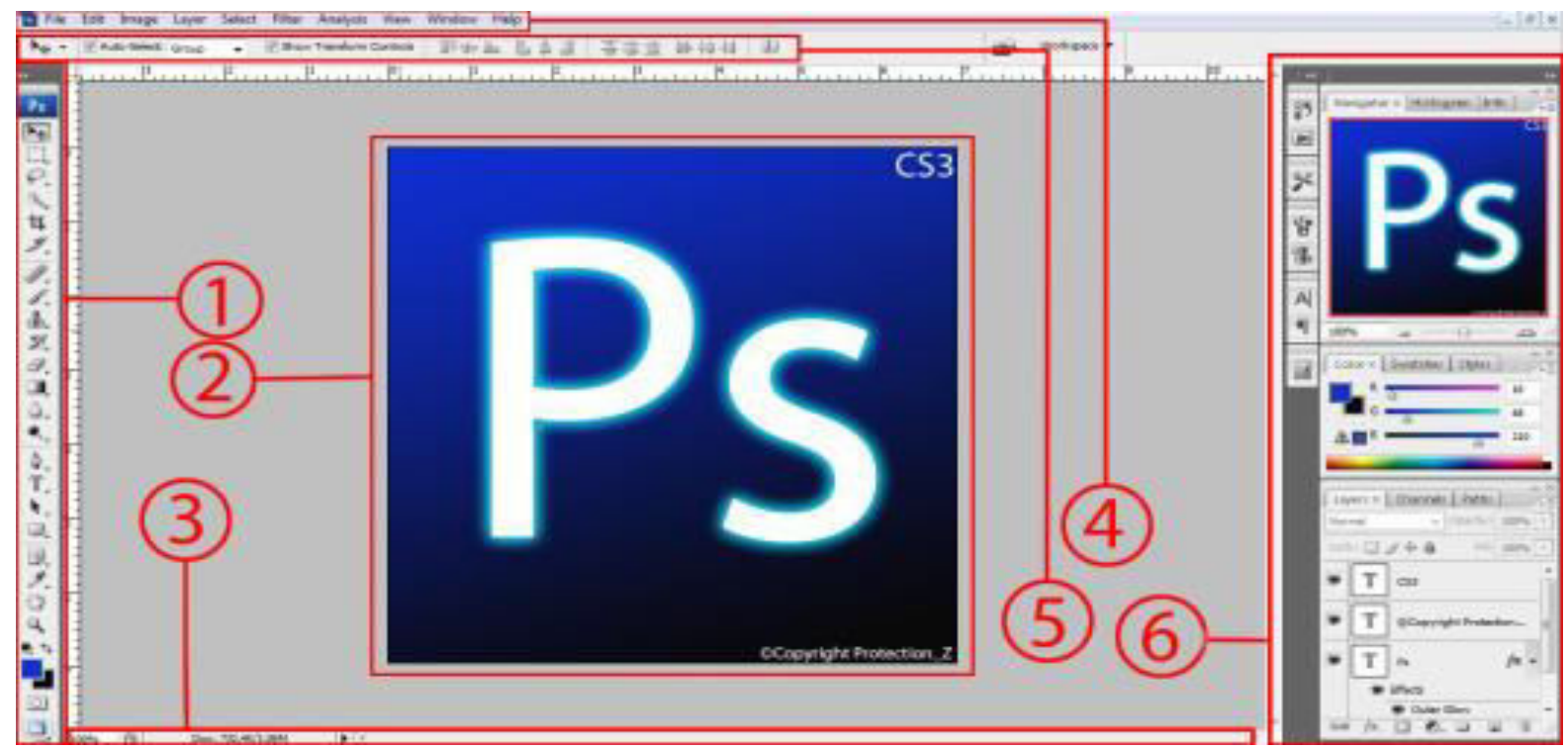

Gambar 1. Gambar Area Kerja Adobe Photoshop

Dalam area kerja adobe photoshop tersebut itulah yang akan digunakan untuk whorshop. Hal-hal yang di dalam photo editing menggunakan bantuan photoshop adalah (1) Cara Membuat Dokumen Baru Pada Photoshop, (2) Membuka dokumen di Photoshop, (3) Membuka dokumen di Photoshop, (4) Cara Mengubah Ukuran Gambar dan Kanvas Pada Photoshop, (5) Memotong Gambar Menggunakan Tool CropeDi Adobe Photoshop, (6) Membuat Foto Hitam-Putih, (7) Membersihkan Noda dengan Healing Brush, (8) Menambal Noda dengan Patch

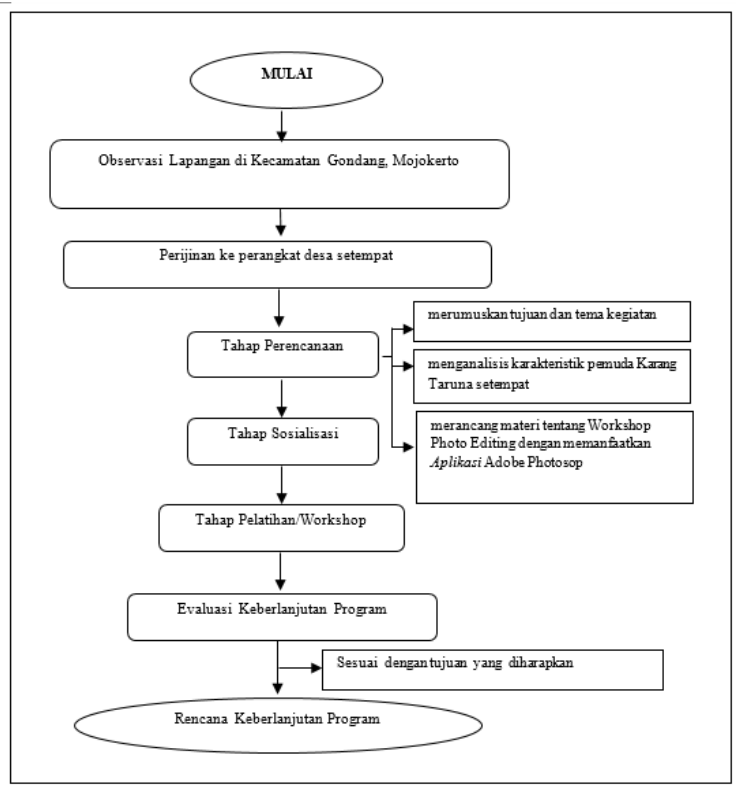

Bagan 1. Diagram Alur Kegiatan PPM

\section{HASIL DAN PEMBAHASAN}

Kegiatan PPM ini telah berhasil dilaksanakan oleh Tim Program Studi Pendidikan Matematika Fakultas Keguruan dan Ilmu Pendidikan Universitas PGRI Adi Buana yang bekerja sama dengan Kelompok Pemuda Karang taruna Se-Kecamatan Gondang. Kegiatan PPM ini dihadiri sebanyak 33 Pemuda dan Pemudi Karang Tarunaese-kecamatan Gondang dari 38 Undangan yang disebar. Pelaksanaan PPM 
ini bertempat di aula kantor kecamatan Gondang. Adapun prosesepelaksanaan kegiatan PPM ini terlaksana dalam beberapa tahapan sebagai berikut :

1. Tahapan Persiapan

Kegiatan yang dilakukan pada tahap persiapan di antaranya :

a. Tahapan Koordinasi Pertama

Koordinasi persiapan kegiatan PPM ini diawali dengan membentuk panitia pada tanggal 02 Februari 2019 melalui rapat program studi. Ada beberapa masukan dari panitia mengenai tema PPM. Kemudian, berdasarkan musyawarah bersama, diputuskan tema PPM mengenai Pelatihan Desain Grafis sebagai Bekal Berwirausaha bagi Pemuda Karang Taruna se-kecamatan Gondang.

b. Tahapan Koordinasi Kedua Panitia PPM melakukan koordinasi dengan pihak desa dan orang-orang dikantor kecamatan gondang terkait mengenai tema, tempat dan waktu pelaksanaan, dan sasaran peserta yang akan diikutsertakan. Koordinasi ini dilakukan pada tanggal 05 Februari 2019. Hasil koordinasi ini berupa ijin pelaksanaan, penetapan tempat dan waktu pelaksanaan, sasaran peserta yang diundang, serta prosedur undangan untuk peserta. c. Tahapan Koordinasi Ketiga

Panitia melakukan diskusi kepada Pihak terkait mengenai kedalaman pemahaman pemuda karang taruna tentang pentingnya keterampilan desain grafis bagi pemuda karang taruna, baik bagi kepentingan berorganisasi maupun sebagai bekal berwirausaha. Hal ini dilakukan agar kegiatan PPM sesuai dengan kebutuhan peseta kegiatan.

d. Tahapan Koordinasi Keempat Berdasarkan hasil diskusi tersebut, disusun materi yang akan disampaikan pada kegiatan PPM. Setelah materinya telah ditetapkan, pada tanggal 7 Februari 2019, diadakan rapat koordinasi panitia untuk menentukan narasumber

e. Tahapan Koordinasi Kelima Pemateri melakukan simulasi mengenai materi yang akan dipresentasikan pada tanggal 8 Februari 2019 di ruang laboratorium komputer program studi Pendidikan Matematika.. Sedangkan, panitia melakukan koordinasi terakhir terkait susunaneacara, formatesertifikat, dan hal - hal lainnya.

2. Tahapan Pelaksanaan

Berikut ini rincian kegiatan pelaksanaan PPM yang dijelaskan dalam Tabel 1 berikut.

Tabel 1: Rincian kegiatan pelaksanaan PPM

\begin{tabular}{|c|c|c|c|c|}
\hline No. & Nama Kegiatan & Sub Kegiatan & $\begin{array}{l}\text { Waktu } \\
\text { Pelaksanaan }\end{array}$ & Keterangan \\
\hline 1 & $\begin{array}{l}\text { Manfaat Belajar } \\
\text { Desain Grafis }\end{array}$ & $\begin{array}{l}\text { Penyampaian materi } \\
\text { mengenai manfaat } \\
\text { belajar desain grafis di } \\
\text { dunia perorganisasian } \\
\text { dan bidang wirausaha }\end{array}$ & $\begin{array}{l}\text { 16 Februari } \\
2019 \\
\text { pukul } \\
08.00-11.00\end{array}$ & Telah selesai \\
\hline 2 & $\begin{array}{l}\text { Pengenalan Fitur- } \\
\text { Fitur pada Aplikasi }\end{array}$ & $\begin{array}{l}\text { Mensosialisasikan } \\
\text { program dan Tools pada }\end{array}$ & $\begin{array}{l}\text { 23eFebruari } \\
2019\end{array}$ & Telah selesai \\
\hline
\end{tabular}




\begin{tabular}{lllll}
\hline & Adobe Photoshop & Aplikasi Adobe & & \\
& & & \\
& & & \\
& & & \\
Photoshop & 08.00-12.00 & \\
Mengedit Foto & Praktek mengedit poto & 09eMaret 2019 & Telah selesai \\
dengan & sederhana oleh peserta & & \\
memanfaatkan & & pukule & \\
Aplikasi Adobe & & $08.00-16.00$ & \\
Photoshop & & & \\
\hline
\end{tabular}

Adapun kegiatan-kegiatan pelaksanaan PPM yang dilaksanakan di Kecamatan Gondang Kabupaten Mojokerto dapat diliat pada Gambar 2, Gambar 3, Gambar 4, Gambar 5 berikut.

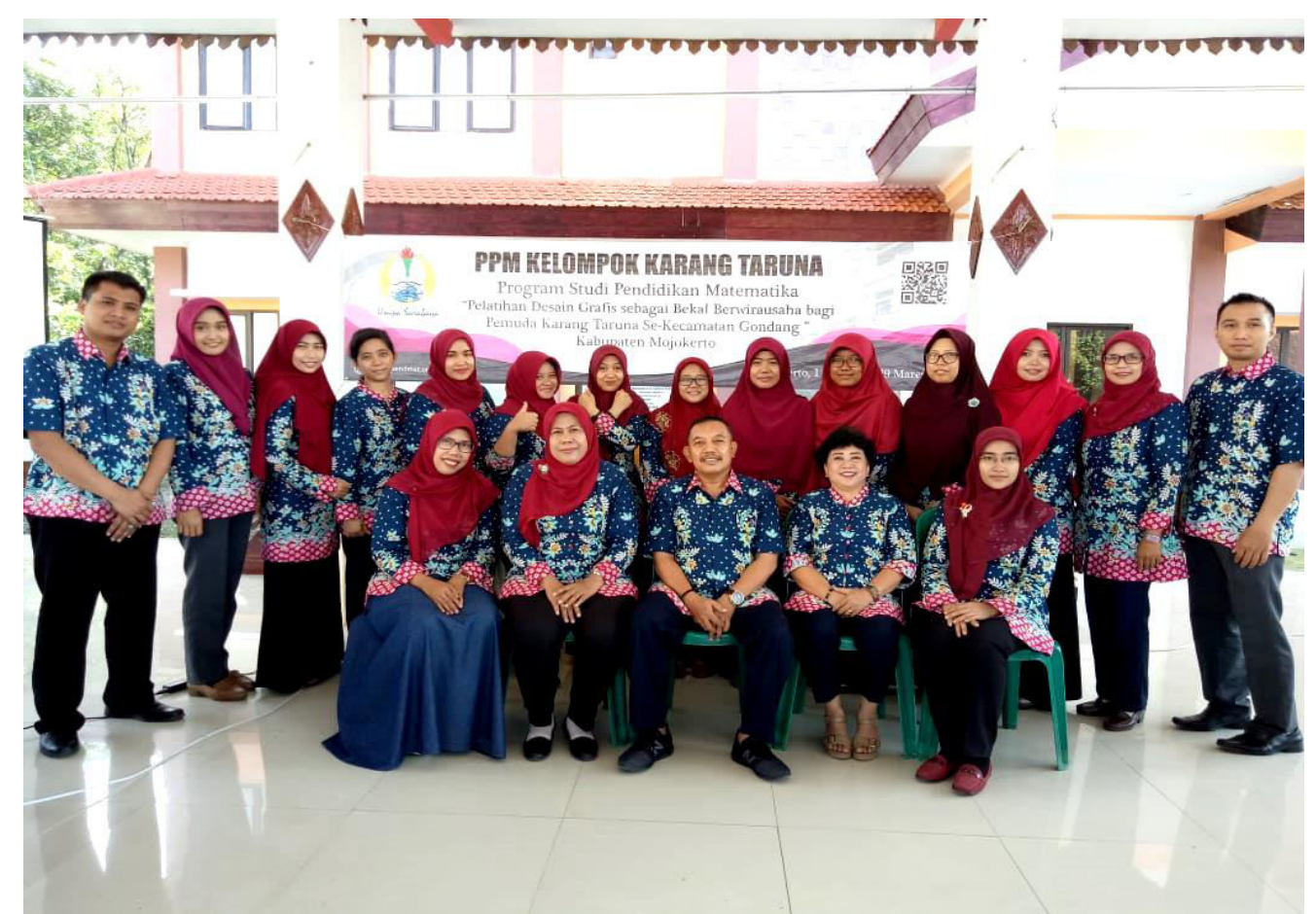

Gambar 2. Whorkshop Photo Editing dengan Adobe Photoshop di Kecamatan Gondang 

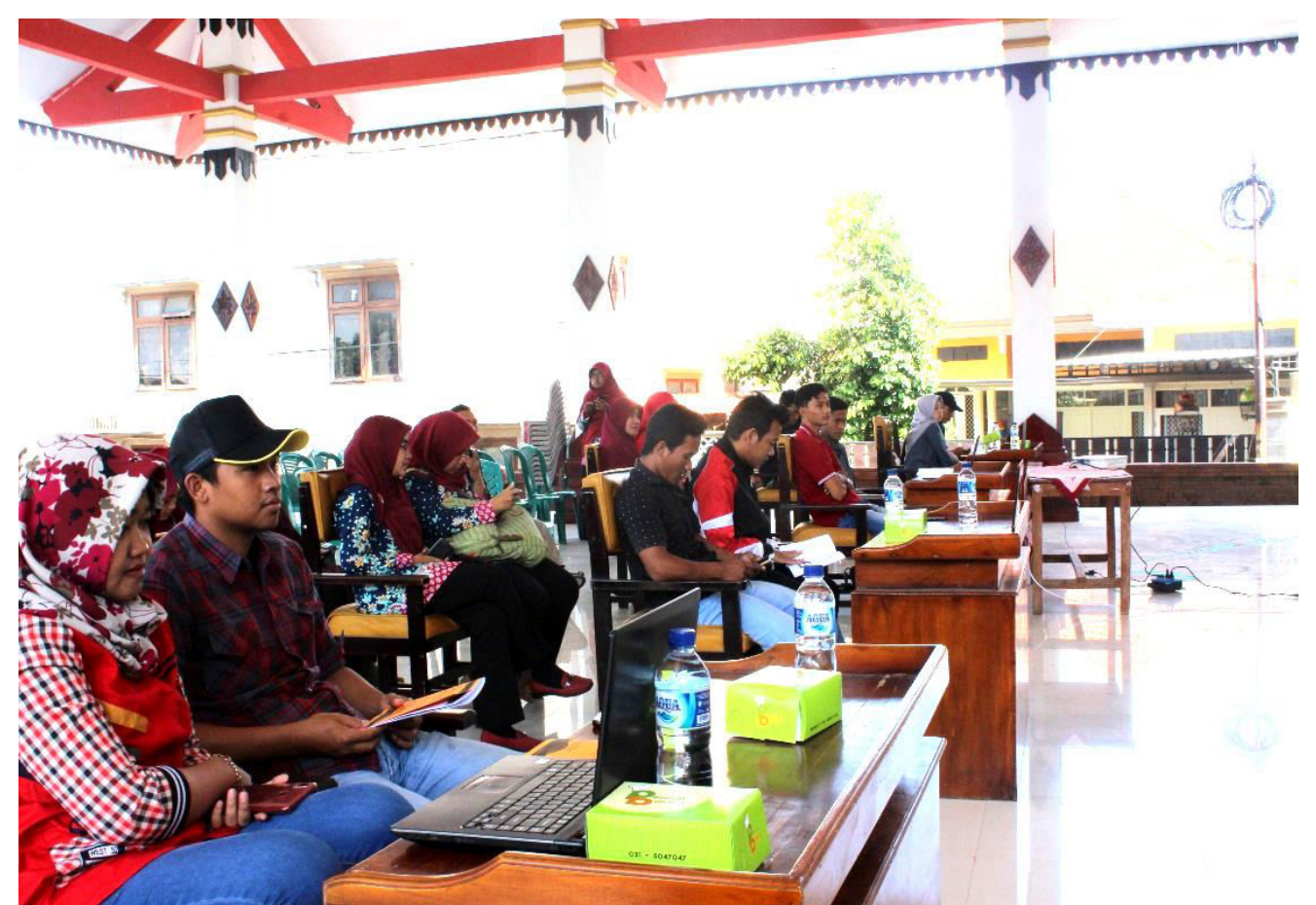

Gambar 3. Workshop Photo Editing dengan Adobe Photoshop di Kecamatan Gondang

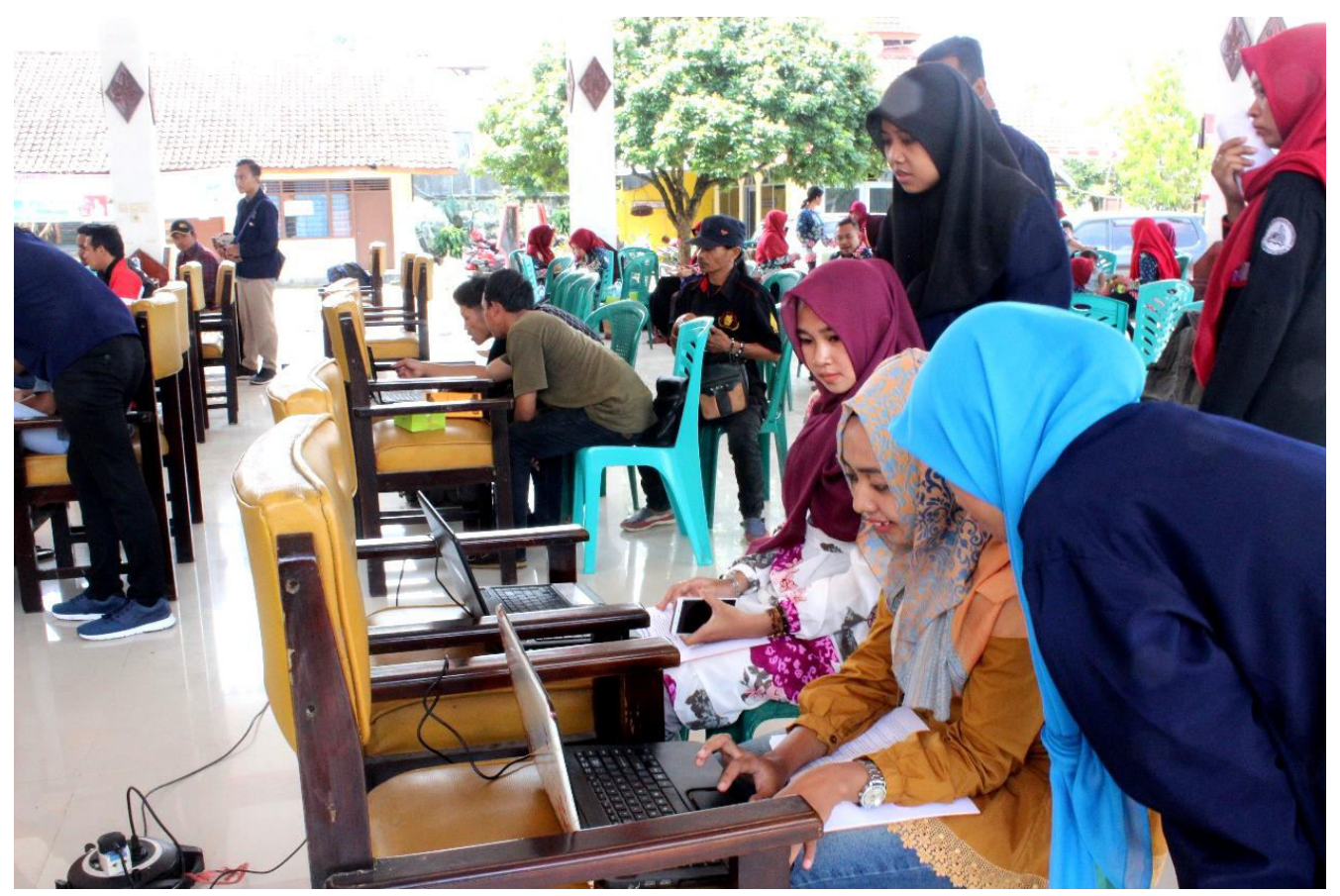

Gambar 4. Workshop Photo Editing dengan Adobe Photoshop di Kecamatan Gondang 


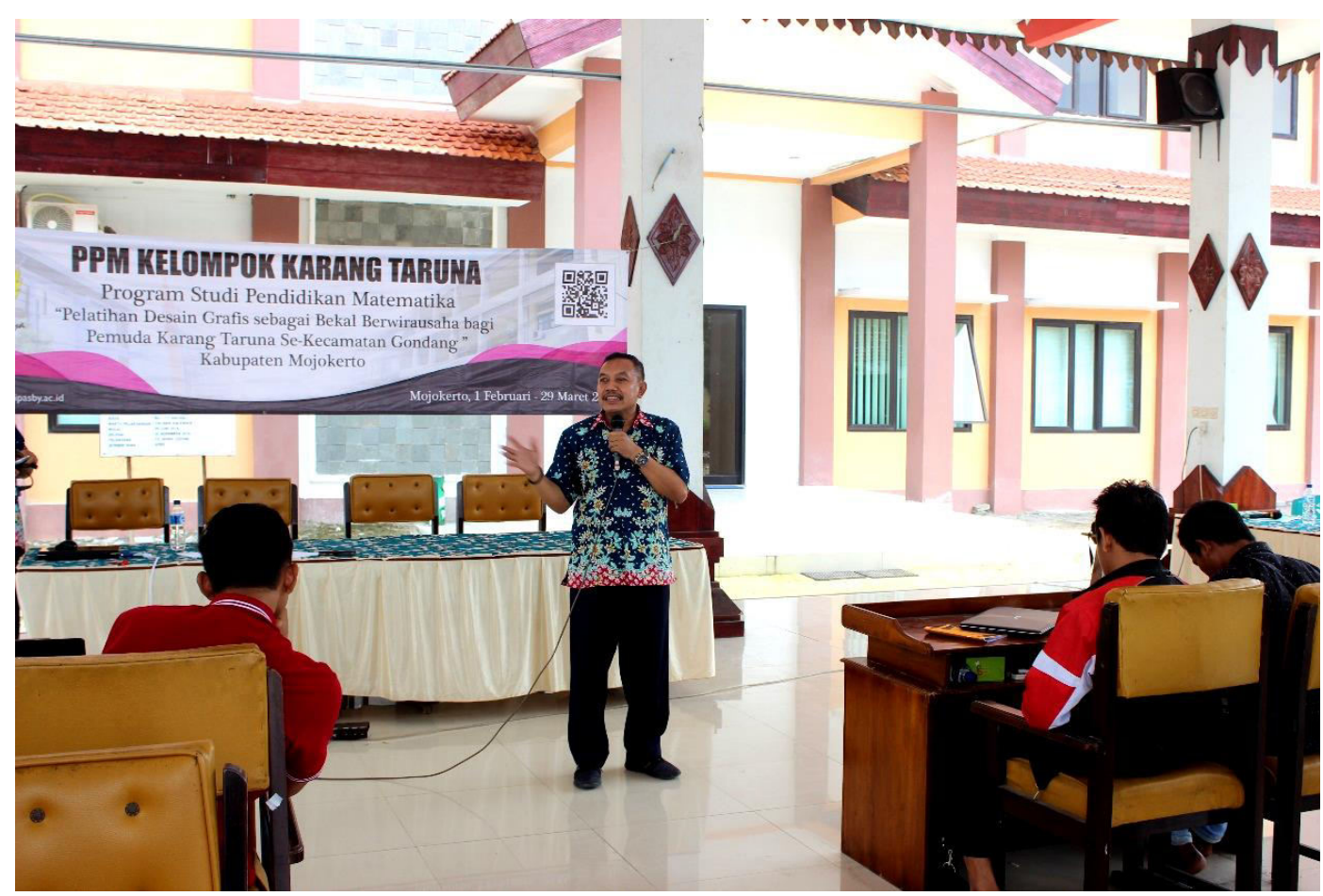

Gambar 5. Whorkshop Photo Editing dengan Adobe Photoshop di Kecamatan Gondang

Pelaksanaan kegiatan Program Pengabdian kepada Masyarakat oleh Tim Dosen Pendidikan Matematika Universitas PGRI Adi Buana Surabaya berjalan dengan lancar. Para peserta sangat antusias mengikuti setiap kegiatan yang sudah terjadwal. Kedatangan peserta selalu tepat waktu yaitu sepuluh menit sebelum kegiatan dimulai. Jika kegiatan melampaui batas waktu sholat dhuhur maupun sholat ashar maka kami mengadakan jeda untuk Ishoma (Istirahat, Sholat, Makan/Coffee break). Semua konsumsi dan coffee break telah disediakan Tim Panitia Dosen Pendidikan Matematika.

Kendala yang dihadapi saat pelaksanaan Program Pengabdian kepada Masyarakat oleh Tim Dosen Pendidikan Matematika Universitas PGRI Adi Buana Surabaya adalah minimnya ketersediaan meja yang dapat menunjang keefektifan kegiatan, karena peserta terlihat kerepotan saat memegang laptopnya.

\section{KESIMPULAN}

Kegiatan pengabdian masyarakat yang telah dilaksanakan berupa: (1) Sosialisasi materi "Manfaat Belajar Desain Grafis"; (2) Sosialisasi materi "Pengenalan Fitur-Fitur pada Aplikasi Adobe Photoshop "; (3) Sosialisasi materi dan workshop "Mengedit Foto dengan memanfaatkan Aplikasi Adobe Photoshop". Peserta berharap adanya workshop lanjutan dengan tema serupa guna pendalaman materi, oleh karenanya berikut hal-hal yang perlu diperhatikan untuk kegiatan serupa berikutnya: (1) Himbauan bagi peserta membawa laptop yang sebelumnya telah terinstal Aplikasi yang akan digunakan, sehingga waktu yang tersedia dapat berjalan dengan efektif sesuai jadwal; (2) Pelaksana harus menyediakan sarana dan prasana yang memadai seperti kabel olor dan meja yang cukup.

Hasil dari kegiatan pengabdian pada masyarakat ini, adalah peserta yang terdiri atas para pemuda atau karang taruna yang mengikuti workshop mampu membuat foto editing dengan menggunakan adobe photoshop. Kegiatan tersebut dapat dijadikan suatu gambaran bagi berbagai pihak terkait untuk dapat memotivasi generasiemuda utamanya karangetaruna agarelebih dapat berkreasi. Setelah terlaksananya kegiatan ini, 
diharapkan karang taruna yang ada di Kecamatan Gondang Kabupaten Mojokerto dapat mengembangkan jiwa berwirausaha dengan keterampilan foto editing dengan menggunakan adobe photoshop.

\section{REFERENSI}

Ebook: Tips dan Trik Adobe Photoshop. http://slametriyanto.net

Hand Out Manipulasi Foto dengan Photoshop. Slamet Riyanto, 20022007.

Hidayat, Heri. 2011. Menjadi Master Photoshop Untuk Pemuia Dari Nol Hingga Mahir. Jakarta: Dunia Komputer.

https://id.wikipedia.org/wiki/Adobe_Photosh op

http://scdc.binus.ac.id/bic/2017/04/548/

https://kuliahdesain.com/cara-edit-foto-diphotoshop/

https://www.acerid.com/2018/03/cara-kerenyang-bisa-kamu-lakukan-denganphotoshop/

https://www.kolomsatu.com/belajar-teknikdasar-editing-foto-menggunakanphotoshop.html

https://herliseptiani.wordpress.com/tutorial/a dobe-photoshop/photoshopdasar/mengenal-area-kerja-adobephotoshop/

https://www.grafismedia.website/2016/09/cara-membuatdokumen-baru-pada-photoshop.html

http://bdesains.blogspot.com/2015/06/caramengubah-ukuran-gambar-dankanvas.html

https://tanduo.wordpress.com/2010/08/29/hea ling-brush-tool/

Khaeruddin. 2005. Belajar Otodidak Adobe Photoshop CS. Bandung : CV. Yrama Widya.

Praktikum Adobe Photoshop CS. Slamet Riyanto. Jakarta: Datakom Lintas Buana, 2004. 115 hal. 
PENAMAS ADI BUANA

Volume 04, Nomor 1, 01 Juli 2020
P ISSN 2622-5727

E ISSN 2622-5395 